\title{
Chemo-enzymatic epoxidation of $\beta$-caryophyllene mediated lipases and by mycelium-bound lipases
}

\author{
Jaqueline M. R. da Silva ${ }^{\star a}$, Maria G. Nascimento ${ }^{a}$ and Sandra P. Zanotto \\ ${ }^{a}$ Departamento de Química, Universidade Federal de Santa Catarina - 88040-900 Florianópolis - SC, Brazil. \\ ${ }^{b}$ Laboratório de Biorgânica, Universidade do Estado do Amazonas , 69050-030 Manaus-AM, Brazil *e-mail: \\ jaquelinemrs@yahoo.com.br
}

Keywords: enzymes, epoxidation, $\beta$-caryophyllene

\section{INTRODUCTION}

A "green" method available for the epoxidation of alkenes (terpenes), based on the perhydrolysis of carboxylic acids and esters, is through the use of lipases (triacylglycerol hydrolases, 3.1.1.3.) in the presence of an oxidizing agent. ${ }^{1,2}$ In this study, twelve commercial lipases from different sources, that is, Candida antarctica B (CAL-B, 10,000 $\mathrm{PLU} / \mathrm{g}$ ); Burkholderia cepacia (PS-C Amano ${ }^{\circledR}$ I, $1.638 \mathrm{U} / \mathrm{g})$; PS Amano ${ }^{\circledR} \mathrm{SD} ; 30,000 \mathrm{U} / \mathrm{g} ;$ PS Amano $^{\circledR}, 30,000 \mathrm{U} / \mathrm{g}$; PS Amano ${ }^{\circledR} \mathrm{IM}, 500 \mathrm{u} / \mathrm{g} ;$ PS-C Amano ${ }^{\circledR}$ II, 1,000 U/g; Rhizopus oryzae $(150 \mathrm{u} / \mathrm{mg})$; Candida rugosa $(30,000 \mathrm{u} / \mathrm{g}) ;$ Pseudomonas fluorescens (26,600 U/g); Aspergillus niger (120,000 $\mathrm{u} / \mathrm{g}$ ); Rhizomucor miehei (5-6 BAUN/g); and Mucor miehei (5-6 BAUN/g), were used in the chemoenzymatic epoxidation of caryophyllene $(0.6 \mathrm{~mL}, 2.5$ $\mathrm{mmol})$ using aqueous hydrogen peroxide $(1.2 \mathrm{~mL}$, $30 \%)$ as the oxidant agent and octanoic acid $(0.16$ $\mathrm{mL}, 1 \mathrm{mmol}$ ) as the acyl donor in dichloromethane at $\sim 25^{\circ} \mathrm{C}$. Also, two native lipases from $A$. niger (LAN $18.2 \mathrm{U} / \mathrm{mL}$ ) and Rhizopus oligosporus, (LRO 14.9 $\mathrm{U} / \mathrm{mL}$ ) isolated from microorganisms of a soil from the Bueno Brandão region (MG, Brazil) ${ }^{3}$, and nine mycelium-bound lipases from Amazon region fungi (UEA_01, UEA_06, UEA_07, UEA_23, UEA_27, UEA_28, UEA_41, UEA_53 and UEA_115) ${ }^{4}$, were screened in this study (Scheme 1).
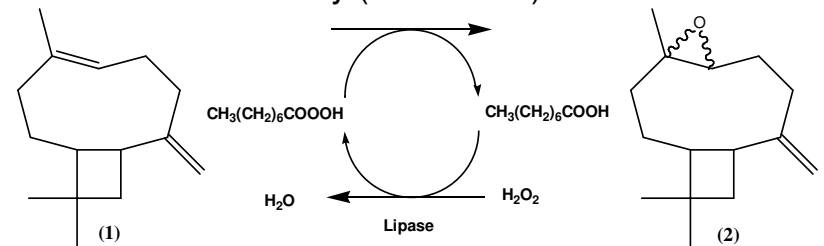

Scheme 1 Chemo-enzymatic epoxidation of caryophyllene

\section{RESULTS AND DISCUSSION}

The epoxidation reaction was maintained under orbital agitation (150 rpm). Aliquots were withdrawn at predetermined times and the epoxy-caryophyllene (2) was quantified by gas chromatography. In the reactions catalyzed by $50 \mathrm{mg}$ of commercial lipases, (2) was obtained in conversion degrees of 16 to $27 \%$. Similar results were obtained with the use of LAN (20\%) and LRO (23\%). The epoxide (2) was obtained in $>99.9 \%$ conversion in a period of $24 \mathrm{~h}$ using CAL-B. In the case of the Amazonian fungi, the influence of time was then evaluated and the results are presented in Table 1.

Table 1. Degree of conversion (\%) of caryophyllene (1) into epoxide (2).

$\begin{array}{ccccc}\text { Mycelium } & \mathbf{2 4} \mathbf{h} & \mathbf{7 2} \mathbf{h} & \mathbf{1 2 0} \mathbf{h} & \mathbf{1 6 8} \mathbf{h} \\ \text { UEA_01 } & 14 & 38 & 43 & 49 \\ \text { UEA_06 } & 16 & 49 & 59 & 64 \\ \text { UEA_07 } & 13 & 38 & 37 & 40 \\ \text { UEA_23 } & 8 & 47 & 49 & 55 \\ \text { UEA_27 } & 2 & 2 & 8 & 8 \\ \text { UEA_28 } & 11 & 42 & 40 & 45 \\ \text { UEA_41 } & 10 & 44 & 47 & 48 \\ \text { UEA_53 } & 21 & 34 & 41 & 41 \\ \text { UEA_115 } & 15 & 29 & 40 & 46\end{array}$

${ }^{*}$ Reaction conditions: caryophyllene $(2.5 \mathrm{mmol}), \mathrm{H}_{2} \mathrm{O}_{2}(5 \mathrm{mmol}$, $30 \%$ ), octanoic acid $(1 \mathrm{mmol})$, mycelium-bound lipases $(100 \mathrm{mg})$, dichloromethane $(10 \mathrm{~mL}), 24 \mathrm{~h}$, r.t

After $24 \mathrm{~h}$ of reaction, the conversion degrees were in the range of $2-21 \%$. For UEA_06 and UEA_53 the results were similar to those obtained using commercial lipases. After $168 \mathrm{~h}$, the best conversion was achieved using UEA_06 (64\%), followed by UEA_23 (55\%), UEA_01 (49\%) and UEA_41 (48\%).

\section{CONCLUSION}

The results obtained are promising and showed the importance of evaluating different sources of biocatalysts for each specific substrate and type of reaction. Depending on the catalyst and reaction time, the epoxide (2) was obtained with moderate to good conversion degrees.

\section{ACKNOWLEDGEMENTS}

UFSC, CNPq, CAPES, INCT-Catálise, Novozymes, Amano and Prof ${ }^{a}$.Dr. ${ }^{a}$ Patricia O. Carvalho (USFBrangança Paulista-SP).

\section{REFERENCES}

1-Björkling, F.; Godtfredsen S. E.; Kirk, O.; J. Chem. Soc, Chem. Commun., 1990, 19, 1301.

2- Michael,J.;. Eisenmenger, J. I.; Reyes-De-Corcuera; Enzyme Microb. Technol., 2009, 45, 331

3- Pilissão, C.; Carvalho, P. O.; Nascimento, M. G.; J. Braz. Chem. Soc., 2010, 21, 973.

4-Zanotto, S. P.; Romano, I. P.; Lisboa, L. U. S.; Duvoisin Jr., S.;Martins, M. K.; Lima, A. L.; Silva, S. F.; Albuquerque, P. M.; J. Braz. Chem. Soc. 2009, 20, 1046.

\footnotetext{
$14^{\text {th }}$ Brazilian Meeting on Organic Synthesis $-14^{\text {th }}$ BMOS - September 01-05, 2011-Brasilia, Brazil
} 